https://doi.org/10.48009/1_iis_2010_211-215

\title{
ACCOUNTING PROFESSIONALS' VALUE ASSESSMENT OF ENTRY LEVEL IT SKILLS AND TOPICS: A COMPARISON OF THE DIFFERENCES BETWEEN CPA FIRMS AND INDUSTRY/GOVERNMENT ORGANIZATIONS
}

Orion J. Welch, St. Mary's University. owelch@stmarytx.edu

Tom Madison, St. Mary’s University, tmadison@stmarytx.edu

Sandra Welch, University of Texas at San Antonio, sandra.welch@utsa.edu

\begin{abstract}
Current accounting professionals were surveyed regarding their perceived value of information systems (IS) classes in preparing accounting students for the work place. The respondents were requested to identify relative importance, in terms of depth of coverage of IS topics in university courses. The topics and skills included programming languages, hardware, office software, database, networks, operating systems, project management, web design and others. The differences between accountants that worked for CPA firms and accountants that worked in industry were analyzed. The results will be useful in developing IS curriculum content for accounting information courses (AIS) and in IS courses that support accounting majors.
\end{abstract}

Keywords: information systems education, information technology skills, accounting information systems, information systems curriculum, revamping curriculum

\section{INTRODUCTION}

The passage of the Sarbanes-Oxley act in 2002 created an increased pressure on the accounting and internal auditing departments of public companies. Prior to the passage of this act the general progression for accounting students had been to start their careers with public accounting firms and later move over into the industry or government sectors. The impact of these changes in the regulatory environment has caused an increase in the demand for internal and IT auditors. This development in the employment market may make students value the enhancement of knowledge and skills in information systems in accounting or in information systems [8].

The accounting departments at the authors' universities noted that industry firms, especially in the internal audit area, started successfully recruiting university students into internships and attracting top accounting students to start their careers in industry. CPA firms typically focus on the taxation and auditing specialty areas. The functions that beginning accountants in non-CPA firms might be involved with early in their careers may be much broader in scope.

Many public universities have faced cutbacks from state funding, and private universities have had their scholarship endowment reduced by downturns in the economy. There has been pressure to reduce the number of hours in undergraduate degree programs to promote four-year graduation rates and offset the increasing cost of education for their students. In light of these issues, it is important that course design focus on skills and topics that that are important to the employment market.

This paper examines what IS skills and topics are identified as being most critical for entry-level accounting positions. It also examines whether there are differences in technology, data analysis, and project management skills/knowledge expected of entry level accounting graduates between CPA firm employers and industry or government employers. This information might be useful in developing accounting and information system class curriculum to support university programs.

\section{IMPORTANCE OF TECHNOLOGY IN ACCOUNTING CURRICULUM}

There is substantial commentary in accounting education circles related to including IS curriculum in accounting education. The American Institute of Certified Public Accountants has included learning to "leverage technology" as an important skill for those wishing to enter the accounting profession. The AICPA's Core Competency Framework suggests that technology skills are an essential element of personal competencies, functional competencies, and development of broad business understanding, all three of which are critical for the professional success of young accounting professionals [1]. Problem solving and project management skills were also indentified as key personal competencies by the AICPA [1]. Both of the areas are also addressed in 
IS curriculum. Daigle, Hayes, and Hughes [7] proposed developing skills-based curriculum promulgated in the AICPA framework because of the dynamic and evolving nature of the knowledge used by accounting professionals.

The substantial importance with which the AICPA views the ability to leverage technology is also illustrated by the fact that several technology topics are now covered in the CPA examination. These topics include roles and responsibilities within the information technology function; the role of business information systems; and information technology fundamentals, such as hardware, software, data structure, systems operation, and database management [2].

An exhaustive study of accounting educators' and accounting professionals' opinions about accounting education by Albrecht and Sack [3] recommended consideration of joint accounting/information systems degrees. Welch, Madison and Welch [10] found support from accounting professionals for joint information systems degrees in obtaining the 150 credit hours required by many states to sit for the CPA exam. Brown's [4] study suggested that including coursework in IS as a double major could be a way to interest students in the IS major.

Thus, the 150-hour requirement, contemporary critiques of accounting education, and the increased regulatory environment may influence accounting degree programs to emphasize IS topics and skills.

Albrecht and Sack [3] suggest that the business environment is rapidly changing due to globalization and evolving technology. As a result, accounting faculty must continuously evaluate their program to insure that they are preparing graduates with the skills and content knowledge needed by today's accounting professional. Badua's recent study [5] examined topic coverage in AIS syllabi from 56 colleges and universities. His study found accounting software, systems analysis, data and process modeling, database software, security and controls, and e-commerce were the most emphasized topics. An essential element of program assessment must always be the needs of major stakeholders, and a key stakeholder is the employers of a program's graduates. We therefore designed this study to determine employers' opinions about the amount of IS coverage of topics and skills that were preferred for entry level accounting professionals.

\section{METHOD}

The survey population was 2,300 professional accountants. Usable surveys were returned by 440 individuals for a response rate of approximately $20 \%$. The response rate is comparable to that reported in similar studies. Albrecht and Sack [3] report a response rate of approximately $20 \%$. Burnett [6] reports $27.6 \%$ from employers and $21.7 \%$ from private corporations and non-Big 4 firms. Ulrich et al. [9] report $27.2 \%$ from a random sample of national firms with at least 50 professionals. The returned surveys had roughly equal representations of CPA firms and industry or government sectors. One section of the survey requested the respondent's preferences for generic subject areas coverage in traditional business school cores. Respondents were asked to indicate (1) not important no courses, (2) somewhat important part of a course, (3) moderately important one course, (4) very important more than one course. The higher the rating, the more extensive the topic coverage is recommended. Another section of the survey requested preferences on specific IS topics and skills that could be considered important for accounting students to have prior to initial employment, the principal focus of this paper. The topics/skills were selected from material typically covered in the core Management Information Systems courses. For each topic or skill, respondents were asked to indicate if they believed it is a skill that (1) is not important, (2) important but not critical, or (3) critical for new hires to know. The higher the score the greater the respondents viewed the importance of the topic/skill.

\section{RESULTS AND DISCUSSION}

In the generic subject areas, only three nonaccounting subject areas had average preference ratings higher than 3.0 on a 1 to 4 scale. Those in order of preference were ethics (3.47), finance (3.39), and information systems (3.08). Four other areas, business strategy (2.98), economics (2.82), electronic commerce (2.72) and statistics (2.65), had rating averages above 2.5. These results support the importance for inclusion of IS coursework in the curriculum of accounting students.

Ranked from highest to lowest, the top 10 average ratings by both accountants working in CPA firms and those working in industry or government of the IS skill/topic coverage are shown below. The rating scale used in this case was a 1 to 3 scale. 


\section{TABLE 1 - TOP RANKED TOPICS/SKILLS}

\begin{tabular}{lc} 
CPA Firms & Average Rating \\
\cline { 2 - 2 } Excel & 2.91 \\
Word Processing & 2.75 \\
Windows Software & 2.63 \\
Internet Research & 2.59 \\
Presentation Software & 2.15 \\
Computer Auditing & 2.12 \\
Technology Terminology & 2.07 \\
Database Software & 2.05 \\
IT Security \& Controls & 2.03 \\
Computer Hardware & 1.99 \\
& \\
& \\
Industry/Government & Average Rating \\
Excel & 2.96 \\
Word Processing & 2.73 \\
Windows Software & 2.72 \\
Presentation Software & 2.38 \\
Internet Research & 2.35 \\
Database Software & 2.34 \\
Technology terminology & 2.14 \\
Project Management & 2.11 \\
IT Security \& Controls & 2.06 \\
Data Analysis & 2.02
\end{tabular}

A complete breakout of each category included in the survey and the p-value of the t-test for differences by skill/topic category between the two groups of accountants is identified below.

In Table 1 it is interesting to note that the top three categories are rank-ordered the same for both groups of accountants. Skills in Excel, word processing and Windows software are considered critical by both groups. Internet research, presentation software, database software and IT security and controls also are listed in the top ten of both groups. Computer auditing software is ranked as higher in importance for the CPA firm group, while data analysis and project management are ranked as important in the industry and government group. This makes sense given the differing job functions of each group. While accountants of both groups may be involved in all three of these areas from time to time, auditing functions are a major component of CPA firms. In government and industry accounting operations accountants are more likely to be involved in day-today data analysis and project management-related functions.

We then compared the average score assigned by accountants working in CPA firms versus those assigned by accountants working in industry/ government. Means tests were run using SPSS.
There were 200 respondents from CPA firms and 240 respondents from industry and government organizations. Where there were unequal variances between the two groups the p-value for the unequal variance test results are reported.

\section{TABLE 2 - SCORE COMPARISON}

$\begin{array}{lccc}\begin{array}{l}\text { Information Systems } \\ \quad \text { Skill/Topic }\end{array} & \begin{array}{c}\text { CPA } \\ \text { Firms }\end{array} & \begin{array}{c}\text { Industry/ } \\ \text { Gov't. }\end{array} & \begin{array}{c}\text { p- } \\ \text { value }\end{array} \\ \begin{array}{l}\text { Computer auditing } \\ \text { Telecommunications }\end{array} & 2.12 & 1.89 & 0.00 \\ \text { software } & 1.84 & 1.76 & 0.22 \\ \text { Computer Hardware } & 1.99 & 1.93 & 0.30 \\ \text { Database software } & 2.05 & 2.34 & 0.00 \\ \text { Data analysis } & 1.90 & 2.02 & 0.06 \\ \text { Web design } & 1.17 & 1.27 & 0.02 \\ \text { Graphics software } & 1.52 & 1.50 & 0.72 \\ \text { Intranets } & 1.53 & 1.76 & 0.00 \\ \text { Extranets } & 1.49 & 1.64 & 0.02 \\ \text { Windows software } & 2.63 & 2.72 & 0.08 \\ \text { Presentation software } & 2.15 & 2.38 & 0.00 \\ \text { Programming } & & & \\ \text { languages } & 1.17 & 1.29 & 0.01 \\ \text { Excel } & 2.91 & 2.96 & 0.07 \\ \text { IT Security \& controls } & 2.03 & 2.06 & 0.57 \\ \text { Technology } & & & \\ \text { terminology } & 2.07 & 2.14 & 0.23 \\ \text { Operating systems } & 1.40 & 1.47 & 0.22 \\ \text { Word processing } & 2.75 & 2.73 & 0.61 \\ \text { Internet research } & 2.59 & 2.35 & 0.00 \\ \text { Client/server } & & & \\ \text { management } & 1.52 & 1.50 & 0.67 \\ \begin{array}{l}\text { Project management } \\ \text { Systems analysis }\end{array} & 1.92 & 2.11 & 0.00 \\ \text { Technology } & 1.56 & 1.67 & 0.08 \\ \text { management } & 1.53 & 1.77 & 0.00 \\ \text { Collaboration } & & & \\ \text { software } & 1.61 & 1.65 & 0.57 \\ \text { IT operations } & 1.56 & 1.93 & 0.00\end{array}$

At the .05 significance level, accountants working at CPA firms more highly valued information technology skills in the areas of computer auditing and internet research skills: the first critical to both auditing and tax practice, and the latter to tax practice. Accountants working in industry or government valued database software, presentation software, project management, and IT operations more highly. Differences in importance of skills related to understanding of intranets, extranets, programming languages, and technology management were also significantly more valued within government and industry, but both groups 
rated those categories on average less than "important but not critical" on the 1 to 3 scale.

Seven of the nine significant differences noted in Table 2 reflect the rating a skill/topic as more important to accountants working in industry or government than to accountants working in CPA firms. Therefore, in addition to the tests for each topic/skill, a means test was calculated across all technology topics/skill areas. The accountants in industry or government significantly valued IT skills and topics higher in importance at a p-value of 00.

\section{SUMMARY AND CONCLUSIONS}

One of the most striking outcomes of the study is the extremely strong support among both groups over the importance of highly advanced Excel skills expected of entry-level accountants. These results and subsequent discussions with industry representatives as well as assessment from internships, has resulted in increased emphasis on Excel skills throughout the math, IS, and accounting curriculum at the authors' school.

A second noticeable outcome is that, while there is relative agreement between CPA firm and industry or government accountants on the top five IS skill areas, there are important differences in other IT areas that should be considered. Database software and project management skills are more important in industry or government. Only audit software expertise and intranet research are more important to accountants in CPA firms. Also, broader IT skills expertise is supported as being more important to students planning to begin their careers with industry or government organizations. At the authors' universities, non-CPA organizations have competed successfully with CPA firms in hiring their strongest students. If accounting students are interested in beginning their careers in the industry or government sectors, providing not only curriculum options for development of additional IS and project management skills, but also counseling the students to include specific IS courses when they develop their degree plans may be indicated. Depending on the nature of their accounting students' employment market, college IS departments may want to discuss providing instruction in the topics noted above with their accounting counterparts.

A third outcome is that there are clear differences between our findings and skills/ topics being taught according to Badua's study [5]. This may indicate a lack of alignment between AIS curriculum and the skills and topic coverage reported as most valued by

Volume XI, No. 1, 2010 accounting professionals in our study. While there is some rationale that topics such as advanced Word Processing and Presentation Software skills are likely covered in freshman level technology courses and then amplified in other courses, the findings of this study clearly support inclusion of advanced Excel and Windows software within the AIS and Information Systems curriculum. Room might be found by reducing topics for which our study indicates AIS courses may provide too much coverage: systems analysis-type modeling (DFDs, ER diagrams, flow charts, etc.) and e-commerce.

\section{REFERENCES}

1. AICPA (2010). Core Competency Framework. http://ceae.aicpa.org/.

2. AICPA (2010). CPA Exam Specifications. http://www.cpa-exam.org/

3. Albrecht, W.S., and Sack R. (2000, Volume 16). Accounting Education: Charting the Course through a Perilous Future. Accounting Education Series, American Accounting Association. Sarasota, FL. p. 62.

4. Brown, C. Developing a marketing strategy to increase enrollment. Issues in Information Systems, Volume VIII, No, 2, 2007 pp. 1-6.

5. Badua, Frank (2010, May/June). Pedagogy and the PC: Trends in the AIS Curriculum. Journal of Education Business, pp. 259-264.

6. Burnett, S. (2003, Volume 78). The future of accouning education: a regional perspective. Journal of Education for Business, pp. 129-134.

7. Daigle, R., Hayes, D. and Hughes, K. (2007, Vol.21, No.1). Assessing student learning outcomes in the introductory accounting informations systems course using the AICPA's core competency framework. Journal of Information Systems, pp. 149-169.

8. Merhout, J. and Buchman S. (2007, Winter, Vol. 18 Issue 4). Requisite Skills and Knowledge for Entry-level IT Auditors. Journal of Information Systems Education, pp. 469-476.

9. Ulrich, T., Michenzi, A., and Blouch, W. (2003, Spring). CPA's assess the development of professional skills of recent accounting 
graduates. Journal of the Academy of Business Education, pp. 126-137.

10. Welch, O, Madison, T. and Welch, S. (2008, Volume IX, No. 1). Is there working professionals' supporting for recommending students double major in accounting and information systems. Issues in Information Systems, pp. 160-164. 